\title{
Can tooth bleaching agents cause genotoxicity in the oral epithelium? A systematic
}

\section{review with meta-analysis}

\author{
Os agentes clareadores dentais podem causar genotoxicidade no epitélio oral? Uma revisão
} sistemática com metanálise

¿Pueden los agentes blanqueadores dentales causar genotoxicidad en el epitelio bucal? Una revisión sistemática con metanálisis

Liciane dos Santos Menezes ORCID: https://orcid.org/0000-0002-4971-2354 Federal University of Bahia, Brazil E-mail: licianesmenezes@gmail.com

Patrícia Miranda Leite Ribeiro ORCID: https://orcid.org/0000-0002-4243-6887 Federal University of Bahia, Brazil

E-mail: patricia.leiteribeiro@gmail.com

Wilton Mitsunari Takeshita

ORCID: https://orcid.org/0000-0001-5682-1498 Federal University of Sergipe, Brazil E-mail:wmtakeshita2@gmail.com

\begin{abstract}
Objective: To assess, with a systematic review (SR) with meta-analysis, the occurrence of genotoxic effects on the oral epithelium after exposure to tooth bleaching agents. Material and methods: This review was performed according to the PRISMA protocols. To identify relevant studies, a systematic search was performed in the following electronic databases: PubMed, Scopus, Embase, LILACS, and Google Scholar. The research question was "Can tooth bleaching agents cause genotoxicity in the oral epithelium?". The treatment effects were defined as the standardized mean difference (SMD) and 95\% confidence intervals (CI) were established. Results: 154 studies were selected and, after screening titles and abstracts, seven full-text manuscripts were assessed for eligibility, of which four studies were included in the meta-analysis. There were no statistically significant differences in the frequency of micronuclei before and after exposure (SMD $=-0.14,95 \% \mathrm{CI}, 0.98$ to $0.60, \mathrm{p}=0.74)$, with a $\mathrm{Tau}^{2}$ index $=1.00 ; \mathrm{Chi}^{2}=70.20$; $\mathrm{p}$ value $<0.00001$; and $\mathrm{I}^{2}$ of $93 \%$, indicating high heterogeneity among the studies. Conclusion: Considering the limitations of the present SR, tooth bleaching agents do not lead to genotoxic damage in the oral epithelium but with a small effect and low level of evidence. In this way, the use of tooth bleaching agents is safe on the oral mucosa but randomized clinical trials that are more standardized in all stages are required to produce more robust evidence.
\end{abstract}

Keywords: Mutagenicity test; Genotoxicity; Tooth bleaching agents; Mouth; Oral mucosa absorption.

\section{Resumo}

Objetivo: Avaliar, por meio de revisão sistemática (RS) com metanálise, a ocorrência de efeitos genotóxicos no epitélio oral após exposição a agentes clareadores dentais. Materiais e métodos: Esta revisão foi realizada de acordo com os protocolos PRISMA. Para identificar os estudos relevantes, foi realizada uma busca sistemática nas seguintes bases de dados eletrônicas: PubMed, Scopus, Embase, LILACS e Google Scholar. A pergunta da pesquisa era "Os agentes clareadores dentais podem causar genotoxicidade no epitélio oral?". Os efeitos do tratamento foram definidos como a diferença média padronizada (DMP) e intervalos de confiança de 95\% (IC) foram estabelecidos. Resultados: 154 estudos foram selecionados e, após triagem de títulos e resumos, sete manuscritos de texto completo foram avaliados para elegibilidade, dos quais quatro estudos foram incluídos na meta-análise. Não houve diferenças estatisticamente significativas na frequência de micronúcleos antes e depois da exposição $(\mathrm{DMP}=-0,14, \mathrm{IC}$ de $95 \%$, 0,98 a 0,60, p = 0,74), com um índice Tau2 = 1,00; Chi2 = 70,20; valor de p <0,00001; e I 2 de 93\%, indicando alta heterogeneidade entre os estudos. Conclusão: Considerando as limitações da presente RS, os agentes clareadores dentais não levam a danos genotóxicos no epitélio oral, mas com um efeito pequeno e baixo nível de evidência. Assim, o uso de agentes clareadores dentais é seguro na mucosa oral, entretanto ensaios clínicos randomizados e mais padronizados em todos os estágios são necessários para produzir evidências mais robustas.

Palavras-chave: Teste de mutagenicidade; Genotoxicidade; Clareadores dentais; Boca; Absorção pela mucosa oral. 


\section{Resumen}

Objetivo: Evaluar, con una revisión sistemática (RS) con metaanálisis, la ocurrencia de efectos genotóxicos sobre el epitelio bucal tras la exposición a agentes blanqueadores dentales. Material y métodos: Esta revisión se realizó de acuerdo con los protocolos PRISMA. Para identificar los estudios relevantes, se realizó una búsqueda sistemática en las siguientes bases de datos electrónicas: PubMed, Scopus, Embase, LILACS y Google Scholar. La pregunta de investigación fue "¿Pueden los agentes blanqueadores dentales causar genotoxicidad en el epitelio oral?". Los efectos del tratamiento se definieron como la diferencia de medias estandarizada (DME) y se establecieron intervalos de confianza (IC) del 95\%. Resultados: Se seleccionaron 154 estudios y, después de seleccionar títulos y resúmenes, se evaluó la elegibilidad de siete manuscritos de texto completo, de los cuales Se incluyeron cuatro estudios en el metanálisis. No hubo diferencias estadísticamente significativas en la frecuencia de micronúcleos antes y después de la exposición (DME = -0,14, IC del 95\%, 0,98 a 0,60, p =0,74), con un índice Tau2 = 1,00; Chi2 = 70.20; p-value $<0.00001$; e $\mathrm{I}^{2}$ de $93 \%$, lo que indica una alta heterogeneidad entre los estudios. Conclusión: Considerando las limitaciones de la presente RS, los agentes blanqueadores dentales no conducen a daño genotóxico en el epitelio oral pero con un efecto pequeño y bajo nivel de evidencia. De esta manera, el uso de agentes blanqueadores dentales es seguro en la mucosa oral, pero se requieren ensayos clínicos aleatorizados que estén más estandarizados en todas las etapas para producir evidencia más sólida.

Palabras clave: Pruebas de Mutagenicidad; Genotoxicidad; Blanqueadores dentales; Boca; Absorción por la mucosa bucal.

\section{Introduction}

Tooth staining results from an association of intrinsic and extrinsic variables. Genetic disorders such as dentinogenesis imperfecta, amelogenesis imperfecta, or pathologies acquired during dental formation are examples of intrinsic factors, as well as the inadvertent ingestion of fluorine in childhood. The deposition of food and beverages on the dental surface and the use of tobacco result in extrinsic staining (Goldberg, et al., 2010; Almeida, et al., 2015). In these cases, esthetic procedures such as tooth bleaching are extensively required due to psychological factors and the need for inclusion and wellbeing of the patient in society (Dahl \& Pallasen, 2003).

Tooth bleaching is a conservative and little invasive esthetic procedure. Although the literature describes different bleaching techniques, at-home tooth bleaching is the most used due to excellent long-term results (Almeida, et al., 2015; Monteiro, et al, 2019). This technique generally implies the use of a bleaching agent applied to an individualized impression tray, which the patient uses in periods varying from 30 minutes to one whole night, for at least two weeks (Almeida, et al., 2015; Alonso De La Peña, et al., 2013).

Studies indicate dentinal hypersensitivity and gingival injury as an unintended consequence of tooth bleaching (Almeida, et al., 2015; Monteiro, et al, 2019; Alonso De La Peña, et al., 2013; Klaric, et al., 2013). As for the safety of using hydrogen peroxide as a bleaching agent, some discussions are raised considering the possible carcinogenic potential. Regarding the biological features of tooth bleaching, there is a consensus about the induction of genotoxic effects on bacterial and culture cells after direct contact with hydrogen peroxide (Dahl \& Pallasen, 2003; Monteiro, et al, 2019; Klaric, et al., 2013). The genotoxic repercussions of hydrogen peroxide result from the formation of free radicals that may damage intracellular structures and modify DNA (Monteiro, et al, 2019; Klaric, et al., 2013).

Examples of DNA injury include single and double DNA strand breaks and the exclusion or insertion of base pairs (Mehta \& Haber, 2014). Most of these DNA damages are corrected by repair mechanisms. However, if damages are frequent or repair mechanisms are inadequate, such injuries could lead to cell death. It is believed that non-repaired DNA damages play an effective role in the etiology of several diseases, the majority of cancers, infertility, and aging (Shrinivas, et al., 2017).

Among the methods used for assessing these potential changes, the micronucleus test represents a minimally invasive, simple, and fast tool used as an exposure biomarker of several genotoxic agents, allowing a correlation to the risk of cancer (Almeida, et al., 2015; Monteiro, et al, 2019). This test is performed in mammals in vivo and detects mutagenic substances that break chromosomes (clastogenic substances) or interfere with the formation of the mitotic spindle, changing the equitable 
distribution of chromosomes during cell division (Flores \& Yamaguchi, 2008). Micronuclei (MN) are formed by the extrusion of whole chromosomes or their fragments during cell division and a portion of chromatin results from aberrant mitoses (Banerjee, et al., 2016; da Fonte, et al., 2018).

The most important aspect of the micronucleus test is allowing to identify an occasional increase in the frequency of mutations in cells exposed to a varied scope of genotoxic agents, providing a reliable measure of rupture and chromosome loss (Flores \& Yamaguchi, 2008). Therefore, it is an important method to assess the genotoxic effect of chemical and physical agents.

Considering the potential relationship of the cell damage caused by bleaching agents and the scarcity of this approach in human beings, this study raised the following question: "Can tooth bleaching agents cause genotoxicity in the oral epithelium?"

\section{Methodology}

This systematic review was performed according to the PRISMA-P protocol guidelines (www.prismastatement.org/Protocols/) (Moher, et al., 2015) with instructions of the Cochrane Manual for systematic reviews (https://training.cochrane.org/handbook) (Leeflang, et al., 2013).

\section{Study design and eligibility criteria}

When using the search strategy of Population, Intervention, Comparison, Outcome, and Design of the study (PICOS) to define the eligibility criteria, the study wants to answer the following question: "Can tooth bleaching agents cause genotoxicity in the oral epithelium?"

Only studies assessing the genotoxicity of tooth bleaching agents in the oral epithelium were included. No language or publication year was imposed. The following exclusion criteria were applied: (1) studies with an irrelevant object of interest, (2) abstracts or indexes, (3) letters to the editors, (4) literature reviews, (5) personal information or short communications, (6) book chapters, (7) patents, and (8) studies with low methodological quality.

\section{Search and resources of information}

To identify relevant studies, a systematic search was performed in the following electronic databases: PubMed, Scopus, Embase, LILACS, and Google Scholar. Manual research was also performed in the cross-references of original articles to identify studies that could not be located in the electronic databases. These procedures were performed to prevent potential selection and publication biases. The search strategy was performed in August 2021.

The descriptors were selected from the Descriptors in Health Sciences (DeCS), Medical Subject Headings (MeSH), and Embase Subject Headings (Emtree). Boolean operators (AND and OR) were used to combine the descriptors and maximize the search strategy with different combinations. All references obtained were exported to the Excel software, in which duplicates were removed. Table 1 presents the search strategy and respective combinations. 
Table 1. Electronic database and search strategy.

\begin{tabular}{|c|c|}
\hline Database & Search strategy (August 2021) \\
\hline $\begin{array}{l}\text { PubMed } \\
\text { https://www.ncbi.nlm.nih.gov/pubmed/ }\end{array}$ & $\begin{array}{l}((((((\text { Mutagenicity Tests) OR (Toxicity Tests, Genetic)) OR (Mutagen Screening)) } \\
\text { OR (Tests, Genetic Toxicity)) OR (Genetic Toxicity Test)) AND (Tooth Bleaching } \\
\text { Agents)) AND (Tooth Whitening Agents) AND (((Oral Cavity) OR (Cavity, Oral)) } \\
\text { OR (mouth)) }\end{array}$ \\
\hline $\begin{array}{l}\text { Scopus } \\
\text { http://www.scopus.com/ }\end{array}$ & $\begin{array}{l}\text { mutagenicity tests AND genotoxicity AND tooth bleaching agents OR tooth } \\
\text { whitening agents OR oral mucosa OR mouth OR oral cavity }\end{array}$ \\
\hline $\begin{array}{l}\text { Embase } \\
\text { http://www.embase.com }\end{array}$ & "mutagen testing" AND "tooth bleaching agent" OR "mouth cavity" \\
\hline $\begin{array}{l}\text { Google } \\
\text { https://scholar.google.com.br/ }\end{array}$ & $\begin{array}{l}((((((\text { Mutagenicity Test) OR (cytotoxicity assays)OR (genotoxicity assays ) OR } \\
\text { (Toxicity Tests, Genetic))OR (Mutagen Screening)) OR (Tests, Genetic Toxicity)) } \\
\text { OR (Genetic Toxicity Test)) AND (Tooth Bleaching Agents) AND (Tooth } \\
\text { Whitening Agents) AND (((Oral Cavity) OR (Cavity, Oral)) OR (mouth)) }\end{array}$ \\
\hline $\begin{array}{l}\text { Lilacs } \\
\text { https://lilacs.bvsalud.org/ }\end{array}$ & "genotoxicity" and "tooth bleaching" \\
\hline
\end{tabular}

Source: Authors.

\section{Study selection}

Two reviewers collected the data independently, at three different times. First, the reviewers discussed the eligibility criteria applicable to $20 \%$ of references to assess potential method errors. Then, the titles were carefully read to exclude studies outside the research scope. The reviewers were not blind to the information of authorship or the name of journals. Studies with an irrelevant subject of interest were excluded.

Next, the two reviewers analyzed the abstracts of the remaining studies independently. In this phase, abstracts that did not address the subject of interest, literature reviews, case reports, and conference abstracts were excluded. Those in which titles met the eligibility criteria but did not have abstracts available were obtained and their full texts were analyzed later.

Finally, the full texts of the remaining studies were assessed and the lists of references were carefully read to identify studies that could not be located. The studies were assessed to verify whether they met the other eligibility criteria. Studies that did not assess genotoxicity from tooth bleaching agents in the oral epithelium were excluded. When the two reviewers did not reach a mutual agreement, a third one was involved to make a final decision. The rejected studies and the reasons for exclusion were recorded.

\section{Collection process and data items}

After screening, the texts of the studies selected were reviewed and the data were extracted systematically, considering authorship, publication year, and country of origin; study population (types of tests); image processing; resources (type of examination, segmentation method, and resources extracted); and achievement of results (classification method, validation method, and accuracy rate).

To ensure consistency among reviewers, a calibration exercise was performed, in which data were extracted jointly from each eligible study. Then, one author collected the information aforementioned and a second author crossed it to confirm the quality of the data extracted. Any disagreement between the reviewers was solved with a discussion with a third author.

\section{Risk of bias in individual studies}

The risk of bias of the studies selected was investigated with the help of the Joanna Briggs Institute (JBI) critical assessment tool (Tufanaru, et al., 2020) for use in systematic reviews of the JBI involving diagnosis accuracy. The following 
questions were used for this assessment: (Q1) Does the study explain what is the 'cause' and what is the 'effect'?; (Q2) Were the participants included in any similar comparisons?; (Q3) Were the participants involved in any comparisons receiving similar treatment/care other than the exposure or intervention of interest?; (Q4) Was there a control group?; (Q5) Were there multiple outcome measurements before and after the intervention/exposure?; (Q6) Was follow-up completed and, if not, were the follow-up differences between the groups properly described and analyzed?; (Q7) Were the outcomes of participants included in any comparisons measured equally?; (Q8) Were the outcome measurements reliable?; and (Q9) Was appropriate statistical analysis used?. Then, according to the tool, the risk of bias was classified as high when the study reached up to $49 \%$ of "yes" score, moderate when the study reached from $50 \%$ to $69 \%$ of "yes" score, and low when the study reached over $70 \%$ of "yes" score.

\section{Data analysis}

A meta-analysis using a random effects model was performed to estimate the genotoxic repercussions of tooth bleaching agents presented in the manuscripts selected. The random effects model with the Der Simonian-Laird method was used to minimize the influence of heterogeneity among the studies included. The standardized mean difference (SMD) was used as an effects measure. To calculate the SMD the means and standard deviations (SD) from each group and result of interest were obtained. The effect size was determined by calculating Cohen's d statistic (Cochran, 1954). A value of 0.2 was considered a small effect, a value of 0.5 was a medium effect, and a value of 0.8 was a large effect. Forest plots were used to graphically display effect sizes and $95 \%$ confidence intervals (CI). A two-tailed $\mathrm{p}<0.05$ was used to determine statistical significance. The heterogeneity among the studies included was analyzed with Cochran's Q test (Cochran, 1954) and quantified with $\mathrm{I}^{2}$ statistics (Higgins \& Thompson, 2002). The analyses will be performed with the REVMAN 5.3 software (Review Manager, 2014).

\section{Quality of evidence}

The GRADE pro GDT software (http://gdt.guidelinedevelopment.org) was used for summarizing the results. The quality of evidence and strength of recommendations were assessed with the Grading of Recommendations, Assessment, Development, and Evaluation (GRADE) tool based on study design, methodological limitations, inconsistency, indirect evidence, imprecision, and other considerations, and classified as high, moderate, low, and very low (Balshem, et al., 2011).

\section{Results}

\section{Data sources}

The search strategy identified 154 potentially relevant studies. After screening titles and abstracts, four full-text manuscripts were assessed for eligibility, and four observational studies (Almeida, et al., 2015; de Geus, et al., 2015; Rezende, et al., 2016; Del Real García, et al., 2019) were included in the meta-analysis. Table 1 and Figure 1 show the study selection flowchart and the specific reasons for exclusions. 
Figure 1. Flowchart of the study selection process.

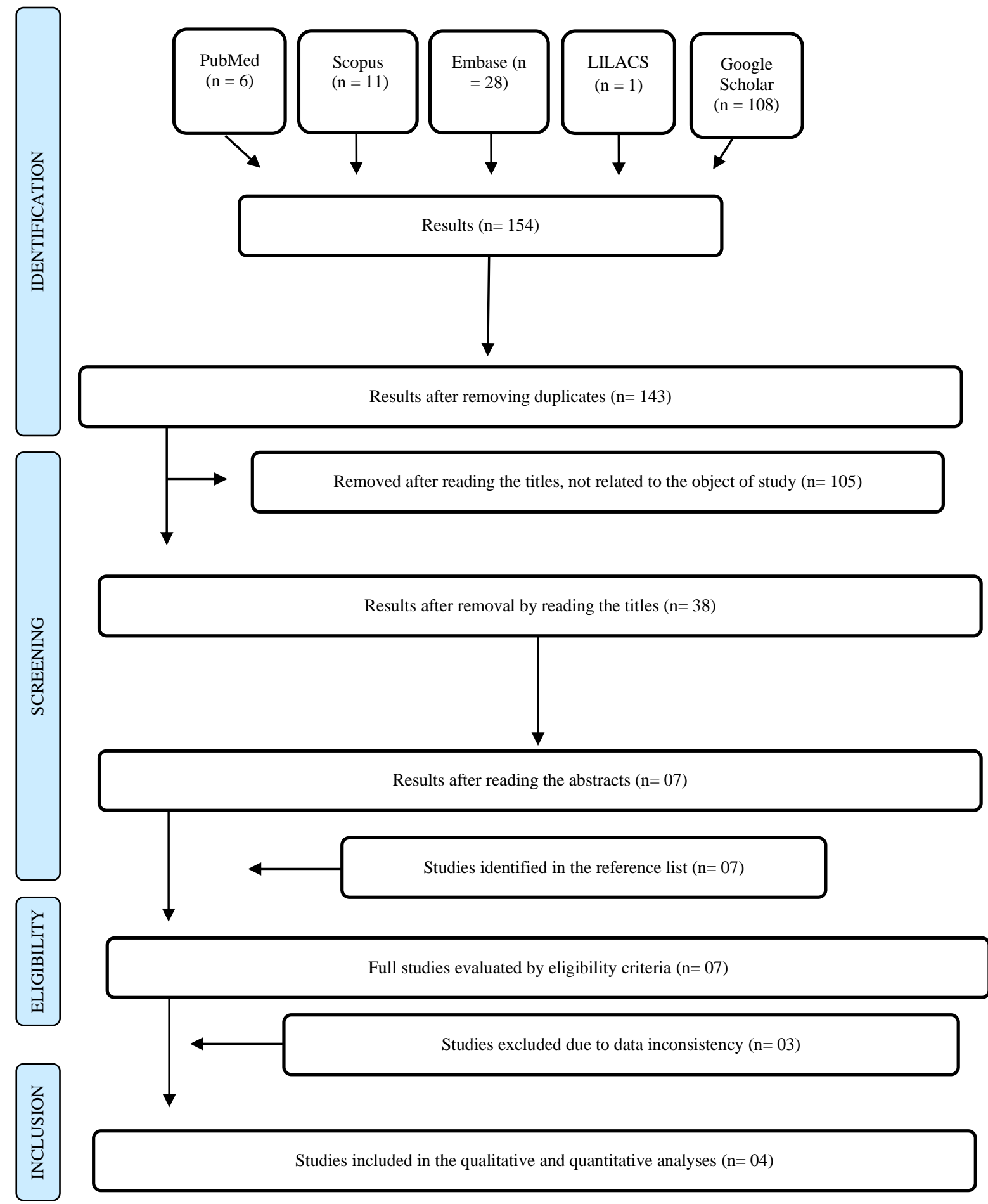

Source: Authors.

\section{Characteristics of the studies}

Table 2 presents the characteristics of the studies. The studies selected performed exfoliative cytology in the oral epithelium 15, 21, and 30 days after exposure to the bleaching gel. As for the site of cell collection, Rezende, et al. (2016) collected cells in the marginal gingiva and anterior upper lip, de Geus, et al. (2015) in the marginal gingiva, Del Real García, et al. (2019) in the buccal mucosa and attached gingiva, and Monteiro, et al. (2019) did not specify the exact site of oral mucosa 
collection. The study with the lowest number of participants was by Monteiro, et al. (2019) and the study with the largest group was by Del Real García, et al. (2019). As for staining, all studies used the Giemsa solution, except for Del Real García, et al. (2019), who used Acridine Orange staining.

Table 2. Characteristics of the studies included in the meta-analysis.

\begin{tabular}{|c|c|c|c|c|c|}
\hline Authors & Year & $\mathrm{N}$ & Bleaching agent & $\begin{array}{c}\text { Nuclear alteration } \\
\text { observed }\end{array}$ & $\begin{array}{l}\text { Staining } \\
\text { reaction }\end{array}$ \\
\hline $\begin{array}{c}\text { de Geus JL Rezende M, Margraf LS, } \\
\text { Bortoluzzi MC, Fernández E, } \\
\text { Loguercio AD, Reis A \& Kossatz S }\end{array}$ & 2015 & 21 & $10 \%$ carbamide peroxide & Micronuclei & Giemsa solution \\
\hline $\begin{array}{c}\text { Rezende M, de Geus JL, Loguercio } \\
\text { AD, Reis A \&Kossatz D }\end{array}$ & 2016 & 30 & $35 \%$ hydrogen peroxide & Micronuclei & Giemsa solution \\
\hline $\begin{array}{c}\text { Del Real García JF, Saldaña-Velasco } \\
\text { FR, Sánchez-de la Rosa SV, Ortiz- } \\
\text { García YM, Morales-Velazquez G, } \\
\text { Gómez-Meda BC, Zúñiga-González } \\
\text { GM, Sánchez-Parada MG \& Zamora- } \\
\text { Perez A L. }\end{array}$ & 2018 & 15 & $10 \%$ hydrogen peroxide & $\begin{array}{c}\text { Micronuclei } \\
\text { Binucleated cells } \\
\text { Nuclear bud } \\
\text { Karyolitic } \\
\text { Karyorrhectic } \\
\text { Condensed chromatin } \\
\text { Pyknotic }\end{array}$ & $\begin{array}{l}\text { Acridine Orange } \\
\text { stain }\end{array}$ \\
\hline $\begin{array}{c}\text { * Monteiro M, Lindoso J, de Oliveira } \\
\text { Conde NC, da Silva LM, Loguercio } \\
\text { AD \& Pereira JV } \\
\text { 1-bleaching tray }\end{array}$ & 2019 & 30 & $10 \%$ hydrogen peroxide & Micronuclei & Giemsa solution \\
\hline $\begin{array}{c}\text { *Monteiro M, Lindoso J, de Oliveira } \\
\text { Conde NC, da Silva LM, Loguercio } \\
\text { AD \& Pereira JV } \\
\text { 2-whitening strips }\end{array}$ & 2019 & 30 & $10 \%$ hydrogen peroxide & Micronuclei & Giemsa solution \\
\hline $\begin{array}{c}\text { *Monteiro M, Lindoso J, de Oliveira } \\
\text { Conde NC, da Silva LM, Loguercio } \\
\text { AD \& Pereira JV } \\
\text { 3- prefilled disposable tray }\end{array}$ & 2019 & 30 & $10 \%$ hydrogen peroxide & Micronuclei & Giemsa solution \\
\hline
\end{tabular}

*Same study but with the same bleaching agent used differently. Source: Authors.

\section{Risk of bias of the studies selected}

Table 3 provides data on the risk of bias of the selected studies assessed with the JBI tool. The studies presented a low risk of bias for the frequencies of micronuclei before and after exposure to the bleaching agent, except for the study by Monteiro, et al. (2019), with a moderate risk of bias. All studies investigated another outcome besides the frequency of micronuclei, such as bleaching action (Almeida, et al., 2015; de Geus, et al., 2015; Rezende, et al., 2016), level of dentinal hypersensitivity (de Geus, et al., 2015; Rezende, et al., 2016), and salivary enzyme analysis (Del Real García, et al., 2019). Only one study did not include patients in similar comparisons and this study also performed different procedures in the groups for outcome measurement (Almeida, et al., 2015). Thus, considering an overall assessment, the studies presented a low risk of bias. 
Table 3. Risk of bias assessed by the Joanna Briggs Institute (JBI) critical assessment tool for the use in systematic reviews of observational studies.

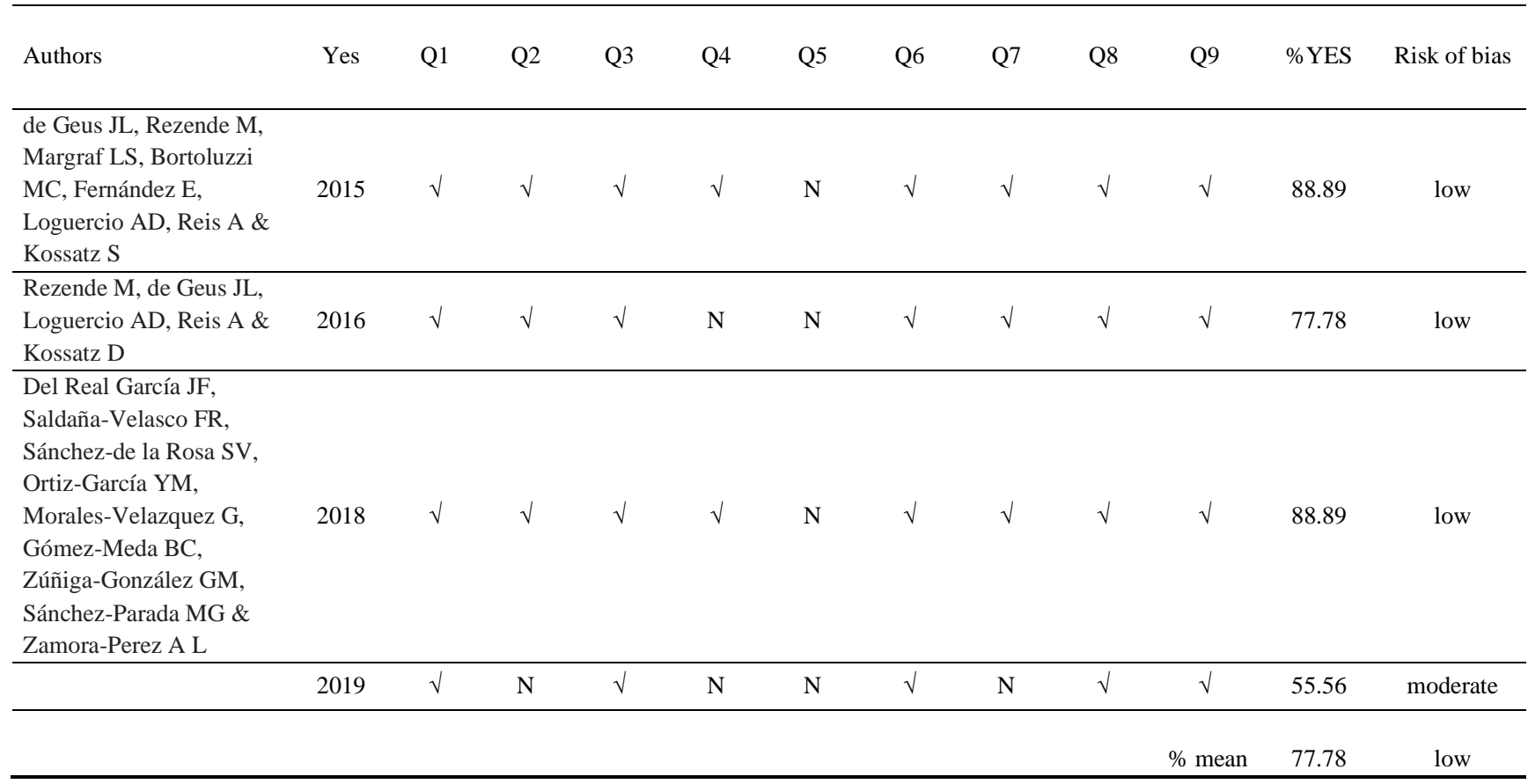

Q1) Does the study explain what is the 'cause' and what is the 'effect'?; Q2) Were the participants involved in any similar comparisons?; Q3) Were the participants involved in any comparisons receiving similar treatment/care other than the exposure or intervention of interest?; Q4) Was there a control group?; Q5) Were there multiple outcome measurements before and after the intervention/exposure?; Q6) Was follow-up completed and, if not, were the follow-up differences between the groups properly described and analyzed?; Q7) Were the outcomes of participants involved in any comparisons measured equally?; Q8) Were the outcome measurements reliable?; Q9) Was appropriate statistical analysis used? $\sqrt{ }$ ) Yes; N) No; U) Uncertain. Source: Authors.

\section{Data synthesis}

The forest plot was used to graphically display effect sizes and 95\% confidence intervals (CI). A two-tailed p $<0.05$ was used to determine statistical significance. Heterogeneity was assessed with Cochran's Q test [15] and quantified with the ${ }^{2}$ index (Higgins \& Thompson, 2002). Indices lower than 25\% indicate low heterogeneity among the studies, moderate heterogeneity between 25 and 75\%, and high heterogeneity above 75\%. A $\mathrm{Tau}^{2}=1.00, \mathrm{Chi}^{2}=70.20$, and p-value $<0.00001$ were found. An $\mathrm{I}^{2}$ value of $93 \%$ was found, indicating high heterogeneity.

According to the meta-analysis, the diamond in the forest plot was displaced to the right side of the null line expressed in the graph. The null hypothesis was accepted, showing that there was no increase in the frequency of micronuclei after exposure to tooth bleaching agents and presenting statistical significance ( $\mathrm{p}=074)$, with a total SMD of -0.14 and $95 \% \mathrm{CI}$ between 0.98-0.69 (Figure 2). 
Figure 2. Forest plot of manuscripts selected.

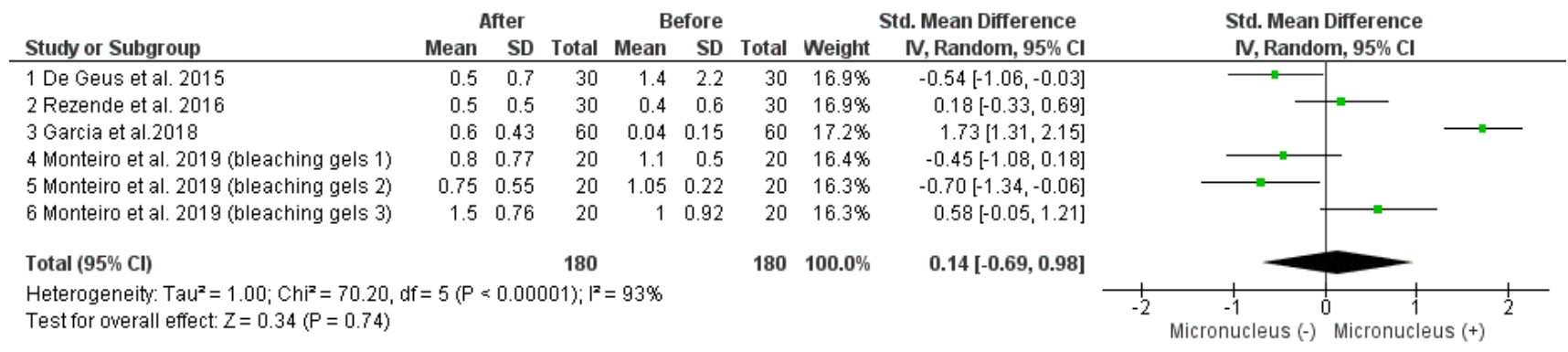

Source: Authors.

\section{Strength of evidence}

The strength of evidence was classified in the result as very low for the effect of tooth bleaching agents on the oral epithelium, using the GRADE approach (Table 4). In this system, the observational studies start as very low evidence, which can be reduced by one or more categories, depending on the risk of bias, heterogeneity, indirect evidence, imprecision, and publication bias (Guyatt, et al., 2011). Hence, the high heterogeneity of the studies helped to reduce the degree of evidence.

Table 4. Grade profile of evidence for studies assessing genotoxicity after exposure to tooth bleaching agents.

\begin{tabular}{|c|c|c|c|c|c|c|c|c|c|c|}
\hline \multicolumn{7}{|c|}{ Certainty assessment } & \multicolumn{2}{|c|}{$\begin{array}{l}\text { Number of } \\
\text { patients }\end{array}$} & Effect & \multirow{2}{*}{ Certainty } \\
\hline $\begin{array}{l}\text { Number } \\
\text { of studies }\end{array}$ & Study design & $\begin{array}{c}\text { Risk } \\
\text { of bias }\end{array}$ & Inconsistency & $\begin{array}{l}\text { Indirect } \\
\text { evidence }\end{array}$ & Imprecision & $\begin{array}{c}\text { Other } \\
\text { considerations }\end{array}$ & Before & After & $\begin{array}{l}\text { Absolute } \\
\text { (95\% CI) }\end{array}$ & \\
\hline 4 & $\begin{array}{c}\text { observational } \\
\text { study }\end{array}$ & $\begin{array}{c}\text { not } \\
\text { severe }\end{array}$ & very severe & not severe & not severe & none & 180 & 180 & $\begin{array}{c}\text { SMD } 0.14 \\
\text { higher } \\
(0.69 \\
\text { lowest to } \\
0.98 \\
\text { highest) }\end{array}$ & $\begin{array}{c}\oplus \bigcirc \bigcirc \bigcirc \\
\text { VERY } \\
\text { LOW }\end{array}$ \\
\hline
\end{tabular}

CI: Confidence interval; SMD: Standardized mean difference. Source: Authors.

\section{Discussion}

The data obtained in the present study showed that tooth bleaching agents are not sufficient to cause genotoxicity in the oral epithelium However, it is worth noting that the effect size was small in the meta-analysis and the quality of evidence was considered very low.

The study of genotoxicity of dental materials is relevant because genotoxicity is related to DNA damage and this is the first mechanism in place during carcinogenesis (Noorimotlagh, et al., 2018). Thus, it is essential to explain to professionals and patients the potential oncogenic risks of these materials. This meta-analysis accesses in vivo studies performed in human beings, indicating the pragmatic conditions.

Among the biomarkers used to measure genetic damages, the micronucleus test is a viable, practical, and low-cost option (Flores \& Yamaguchi, 2008). Micronuclei (MN) originate from fragments or whole chromosomes not included in the main nuclei of daughter cells during cell division. They reflect chromosome damage and may provide a marker of the initial stage of carcinogenesis (de Geus, et al., 2015).

Tooth bleaching can be performed with and without gingival barriers and, in the modality without barriers, the gel contacts the soft tissues of the oral cavity. Previous studies in the literature show that 35 to $50 \%$ of patients reported some type 
of gingival irritation when using hydrogen peroxide at $10 \%$ concentration without using gingival barriers (Cordeiro, et al, 2019).

The bleaching agents most used are carbamide peroxide and hydrogen peroxide. The active substance responsible for tooth bleaching is hydrogen peroxide, considering that carbamide peroxide, when active during bleaching, breaks and produces hydrogen peroxide and urea (Alonso De La Peña, et al., 2013). The potential genotoxicity of tooth bleaching agents can be justified by the result of free radical formation, including the hydroxyl radical, which may damage intracellular structures and DNA (Dahl \& Pallasen, 2003; Klaric, et al., 2013; Ribeiro, et al., 2005; Lucier, et al., 2013).

Among the studies included in the meta-analysis, only one presented statistically significant data for positivity regarding genotoxicity (Del Real García, et al., 2019). This study used 10\% hydrogen peroxide in whitening strips, which is an at-home dental bleaching method that may accidentally have gel contacting the oral mucosa. The method for staining plates was also different. The study was performed with 113 patients, with 53 in the control group and 60 exposed to the bleaching gel, thus highlighting a larger sample size than the other studies of this meta-analysis. Monteiro, et al. (2019) also performed at-home bleaching with the same substance (10\% hydrogen peroxide), but genotoxicity was revealed. Similarly, de Geus, et al. (2015) also performed at-home bleaching but with 10\% carbamide peroxide, and there was no increase in MN.

Only one study (Rezende, et al., 2016) analyzed the effect of 35\% hydrogen peroxide for in-office bleaching on gingival cells and lip, and its results did not indicate an increase in the frequency of MN. The literature reinforces that, because a gingival barrier is used for in-office bleaching, the likelihood of the gel contacting the oral mucosa is controlled (Klaric, et al., 2013). However, Rezende, et al. (2016) explain that a high concentration of hydrogen peroxide may inhibit cell division and the expression of DNA damages, not increasing the frequency of MN.

The post-exposure collection of the bleaching gel was performed at 15 days (Del Real García, et al., 2019), 21 days (de Geus, et al., 2015), and 30 days (Rezende, et al., 2016). According to the literature, the time interval required for cell renovation of the oral epithelium is around 15 days but it may vary from five to seven days, up to 21 days (Holland, et al., 2008). Therefore, the most acute genotoxic effects are expected at this time interval. Regarding the count of the number of cells, all studies counted 1000 cells per plate, which represents the ideal method for determining the frequency of all the various types of cells in a minimum of 1000 cells (Kamboj \& Mahajan, 2007).

As for the site of cell collection, Rezende, et al. (2016) collected cells in the marginal gingiva and anterior upper lip, de Geus, et al. (2015) in the marginal gingiva, Del Real García, et al. (2019) in the buccal mucosa and attached gingiva, and Monteiro, et al. (2019) did not specify the exact site of oral mucosa collection. As for the type of staining, all studies used the Giemsa solution, except for Del Real García, et al. (2019), who used Acridine Orange staining. According to the literature, Giemsa staining is not the most indicated because of the false-positive results in the frequency of MN, leading to an inaccurate assessment of DNA damages. However, in this meta-analysis, the studies using Giemsa staining did not present an increase in the frequency of MN. Using DNA-specific fluorescence staining is recommended and examples of staining methods are Feulgen, propidium iodide, DAPI, Acridine Orange, or Hoechst (Holland, et al., 2008; Kamboj \& Mahajan, 2007). In a comparative study of Acridine Orange and Feulgen staining in the oral mucosa exfoliation of individuals with leukoplakia and squamous cell carcinoma (Thomas, et al., 2009), the authors reported that Acridine Orange was more sensitive to MN detection. However, using Feulgen staining is even more indicated because the plates can be visualized in light microscopy and under fluorescence (Holland, et al., 2008; Kamboj \& Mahajan, 2007). Moreover, choosing this method is suggested because it is classified as the most consistent and DNA-specific and because the other methods still require validation.

The risk of bias in the studies assessed was considered low according to the JBI tool because most answers were positive, except for the measurements before and after exposure to the bleaching agent, in which only one measurement was 
taken instead of multiple ones. However, the micronucleus study only requires a comparison at two times (before and after exposure to the bleaching agent). Moreover, all studies investigated another outcome in the same research besides the frequency of micronuclei, such as bleaching action (Monteiro, et al., 2019; de Geus, et al., 2015; Rezende, et al., 2016), level of dentinal hypersensitivity (de Geus, et al., 2015; Rezende, et al., 2016), and salivary enzyme analysis (Del Real García, et al., 2019).

For the quality of evidence, the GRADE tool was used and showed low evidence, considering that the heterogeneity of studies was high and that the study by García, et al. (2019) presented a different outcome, which may be attributed to the type of genotoxicity analysis used. Thus, further studies are required to strengthen this evidence.

\section{Conclusion}

The evidence presented in this study shows that tooth bleaching agents cannot induce genotoxicity in the oral epithelium of human beings. Considering the limitations of the study, the manuscripts presented a low risk of bias and low quality of evidence because of the expressive heterogeneity of the studies. Therefore, randomized clinical trials that are more standardized in all stages, since selecting the bleaching gel, type of staining, and time of collection, are required to provide more robust evidence and consequently instruct safer clinical practice.

\section{References}

Almeida A. F., Torre E. N., Selayaran M. S., Leite F. R., Demarco F. F., Loguercio A. D., \& Etges A. (2015). Genotoxic potential of 10\% and 16\% carbamide peroxide in dental bleaching. Brazilian oral research, 29:1-7. https://doi.org/10.1590/1807-3107BOR-2015.vol29.0021

Alonso De La Peña, V., Rodriguez Carreira, A., Corral Aneiros, R., López Ratón, M., \& Guitián Rivera, F. (2013). A study of in vivo degradation of two vital home bleaching gels. Dental materials journal, 32(4), 654-658. https://doi.org/10.4012/dmj.2012-317

Balshem, H., Helfand, M., Schünemann, H. J., Oxman, A. D., Kunz, R., Brozek, J., Vist, G. E., Falck-Ytter, Y., Meerpohl, J., Norris, S., \& Guyatt, G. H. (2011). GRADE guidelines: 3. Rating the quality of evidence. Journal of clinical epidemiology, 64(4), 401-406. https://doi.org/10.1016/j.jclinepi.2010.07.015

Banerjee, S., Singh, N. N., Sreedhar, G., \& Mukherjee, S. (2016). Analysis of the Genotoxic Effects of Mobile Phone Radiation using Buccal Micronucleus Assay: A Comparative Evaluation. Journal of clinical and diagnostic research : JCDR, 10(3), ZC82-ZC85. https://doi.org/10.7860/JCDR/2016/17592.7505

Cochran W. G. (1954). The combination of estimates from different experiments. Biometrics, 10:101-129. https://doi.org/10.2307/3001666

Cordeiro, D., Toda, C., Hanan, S., Arnhold, L. P., Reis, A., Loguercio, A. D., \& Bandeira, M. (2019). Clinical Evaluation of Different Delivery Methods of At-Home Bleaching Gels Composed of 10\% Hydrogen Peroxide. Operative dentistry, 44(1), 13-23. https://doi.org/10.2341/17-174-C

da Fonte, J. B., Andrade, T. M., Albuquerque, R. L., Jr, de Melo, M., \& Takeshita, W. M. (2018). Evidence of genotoxicity and cytotoxicity of X-rays in the oral mucosa epithelium of adults subjected to cone beam CT. Dento maxillo facial radiology, 47(2), 20170160. https://doi.org/10.1259/dmfr.20170160

Dahl, J. E., \& Pallesen, U. (2003). Tooth bleaching--a critical review of the biological aspects. Critical reviews in oral biology and medicine : an official publication of the American Association of Oral Biologists, 14(4), 292-304. https://doi.org/10.1177/154411130301400406

de Geus, J. L., Rezende, M., Margraf, L. S., Bortoluzzi, M. C., Fernández, E., Loguercio, A. D., Reis, A., \& Kossatz, S. (2015). Evaluation of genotoxicity and efficacy of at-home bleaching in smokers: a single-blind controlled clinical trial. Operative dentistry, 40(2), E47-E55. https://doi.org/10.2341/14-121-C

Del Real García, J. F., Saldaña-Velasco, F. R., Sánchez-de la Rosa, S. V., Ortiz-García, Y. M., Morales-Velazquez, G., Gómez-Meda, B. C., Zúñiga-González, G. M., Sánchez-Parada, M. G., \& Zamora-Perez, A. L. (2019). In vivo evaluation of the genotoxicity and oxidative damage in individuals exposed to $10 \%$ hydrogen peroxide whitening strips. Clinical oral investigations, 23(7), 3033-3046. https://doi.org/10.1007/s00784-018-2716-3

Flores M. \& Yamaguchi U. M. (2008). Teste do micronúcleo: uma triagem para avaliação genotóxica. Revista Saúde e Pesquisa, 1:337-40.

Goldberg, M., Grootveld, M., \& Lynch, E. (2010). Undesirable and adverse effects of tooth-whitening products: a review. Clinical oral investigations, 14(1), 1-10. https://doi.org/10.1007/s00784-009-0302-4

Guyatt, G. H., Oxman, A. D., Vist, G., Kunz, R., Brozek, J., Alonso-Coello, P., Montori, V., Akl, E. A., Djulbegovic, B., Falck-Ytter, Y., Norris, S. L., Williams, J. W., Jr, Atkins, D., Meerpohl, J., \& Schünemann, H. J. (2011). GRADE guidelines: 4. Rating the quality of evidence--study limitations (risk of bias). Journal of clinical epidemiology, 64(4), 407-415. https://doi.org/10.1016/j.jclinepi.2010.07.017

Higgins, J. P., \& Thompson, S. G. (2002). Quantifying heterogeneity in a meta-analysis. Statistics in medicine, 21(11), 1539-1558. https://doi.org/10.1002/sim.1186 
Research, Society and Development, v. 11, n. 1, e11411124928, 2022

(CC BY 4.0) | ISSN 2525-3409 | DOI: http://dx.doi.org/10.33448/rsd-v11i1.24928

Holland, N., Bolognesi, C., Kirsch-Volders, M., Bonassi, S., Zeiger, E., Knasmueller, S., \& Fenech, M. (2008). The micronucleus assay in human buccal cells as a tool for biomonitoring DNA damage: the HUMN project perspective on current status and knowledge gaps. Mutation research, 659(1-2), 93-108. https://doi.org/10.1016/j.mrrev.2008.03.007

Kamboj, M., \& Mahajan, S. (2007). Micronucleus--an upcoming marker of genotoxic damage. Clinical oral investigations, 11(2), 121-126. https://doi.org/10.1007/s00784-006-0075-y

Klaric, E., Par, M., Profeta, I., Kopjar, N., Rozgaj, R., Kasuba, V., Zeljezic, D., \& Tarle, Z. (2013). Genotoxic effect of two bleaching agents on oral mucosa. Cancer genomics \& proteomics, 10(5), 209-215.

Leeflang, M. M., Deeks, J. J., Takwoingi, Y., \& Macaskill, P. (2013). Cochrane diagnostic test accuracy reviews. Systematic reviews, 2 , 82. https://doi.org/10.1186/2046-4053-2-82

Lucier, R. N., Etienne, O., Ferreira, S., Garlick, J. A., Kugel, G., \& Egles, C. (2013). Soft-tissue alterations following exposure to tooth-whitening agents. Journal of periodontology, 84(4), 513-519. https://doi.org/10.1902/jop.2012.100383

Mehta, A., \& Haber, J. E. (2014). Sources of DNA double-strand breaks and models of recombinational DNA repair. Cold Spring Harbor perspectives in biology, 6(9), a016428. https://doi.org/10.1101/cshperspect.a016428

Moher, D., Shamseer, L., Clarke, M., Ghersi, D., Liberati, A., Petticrew, M., Shekelle, P., Stewart, L. A., \& PRISMA-P Group (2015). Preferred reporting items for systematic review and meta-analysis protocols (PRISMA-P) 2015 statement. Systematic reviews, 4(1), 1. https://doi.org/10.1186/2046-4053-4-1

Monteiro, M., Lindoso, J., de Oliveira Conde, N. C., da Silva, L. M., Loguercio, A. D., \& Pereira, J. V. (2019). Evaluation of the genotoxic potential of different delivery methods of at-home bleaching gels: a single-blind, randomized clinical trial. Clinical oral investigations, 23(5), 2199-2206. https://doi.org/10.1007/s00784-018-2659-8

Noorimotlagh, Z., Mirzaee, S. A., Ahmadi, M., Jaafarzadeh, N., \& Rahim, F. (2018). The possible DNA damage induced by environmental organic compounds: The case of Nonylphenol. Ecotoxicology and environmental safety, 158, 171-181. https://doi.org/10.1016/j.ecoenv.2018.04.023

Review Manager (RevMan) [Computer program]. Version 5.3. (2014). Copenhagen: The Nordic Cochrane Centre, The Cochrane Collaboration.

Rezende, M., De Geus, J. L., Loguercio, A. D., Reis, A., \& Kossatz, D. (2016). Clinical Evaluation of Genotoxicity of In-office Bleaching. Operative dentistry, 41(6), 578-586. https://doi.org/10.2341/15-207-C

Ribeiro, D. A., Marques, M. E., \& Salvadori, D. M. (2005). Assessment of genetic damage induced by dental bleaching agents on mouse lymphoma cells by single cell gel (comet) assay. Journal of oral rehabilitation, 32(10), 766-771. https://doi.org/10.1111/j.1365-2842.2005.01500.x

Shrinivas S. A., Shanta S. H., \& Prajakta B. B. (2017). DNA: Damage and repair mechanisms in humans. Global journal of pharmacy \& pharmaceutical sciences, 3:55561.

Thomas, P., Holland, N., Bolognesi, C., Kirsch-Volders, M., Bonassi, S., Zeiger, E., Knasmueller, S., \& Fenech, M. (2009). Buccal micronucleus cytome assay. Nature protocols, 4(6), 825-837. https://doi.org/10.1038/nprot.2009.53

Tufanaru C., Munn Z., Aromataris E., Campbell J., \& Hopp L. (2020). Chapter 3: systematic reviews of effectiveness. In: Aromataris E, Munn Z (ed). JBI Manual for evidence synthesis. 